\section{PETROGRAPHS AT LAKE PEND D'OREILLE, IDAHO.}

BY JOHN B. LEIBERG, HOPE, IDAHO.

Aboriginal rock carvings or inscriptions are quite rare throughout northern Idaho. The dense forests and generally inaccessible character of the country together with a constant scarcity of natural food products furnished unsuitable conditions to sustain any considerable number of inhabitants, and those that made the country their abode appear to have been either too indolent to endure the labor required to leave any records on the rocks, or their lives did not furnish any events worth noting, in their judgment.

The records we find consist mainly of carving's on trees, or of rocks of small dimensions, raised to perpendicular positions, on the summits of high bare peaks or, in rare instances, in similar situations, of small flat stones arranged in certain geometrical designs, as circles, triangles or circles within circles, or circles and triangles variously intermixed. The carvings on trees all belong to recent years, as very many of them are simply Latin crosses, showing the influence of the missionaries. These crosses schists are rather thinly bedded, have a dip of about $85^{\circ}$ and the wear of the lake in former ages, when its waters stood at a much higher level, has broken the strata apart and left numerous large slabs standing in an upright position. On the face of one of these tablets of rock occur the carving:s as delineated in the accompanying illustration. They occupy a space eighteen feet in length, and from two feet to seven feet in height.

There are twenty-eight figures evidently representing the footprints of the bear, three of the tracks with double sets of toes, three with but four toes, and one with but three toes. Three figures which may represent tracks of the cougar. One arrow head. Three points within circles. One mountain goat. Two sets of circles composed of five and six respectively, and three large figures of unknown meaning. Besides these figures there are evidences of many light scratches, but the lines are too dim

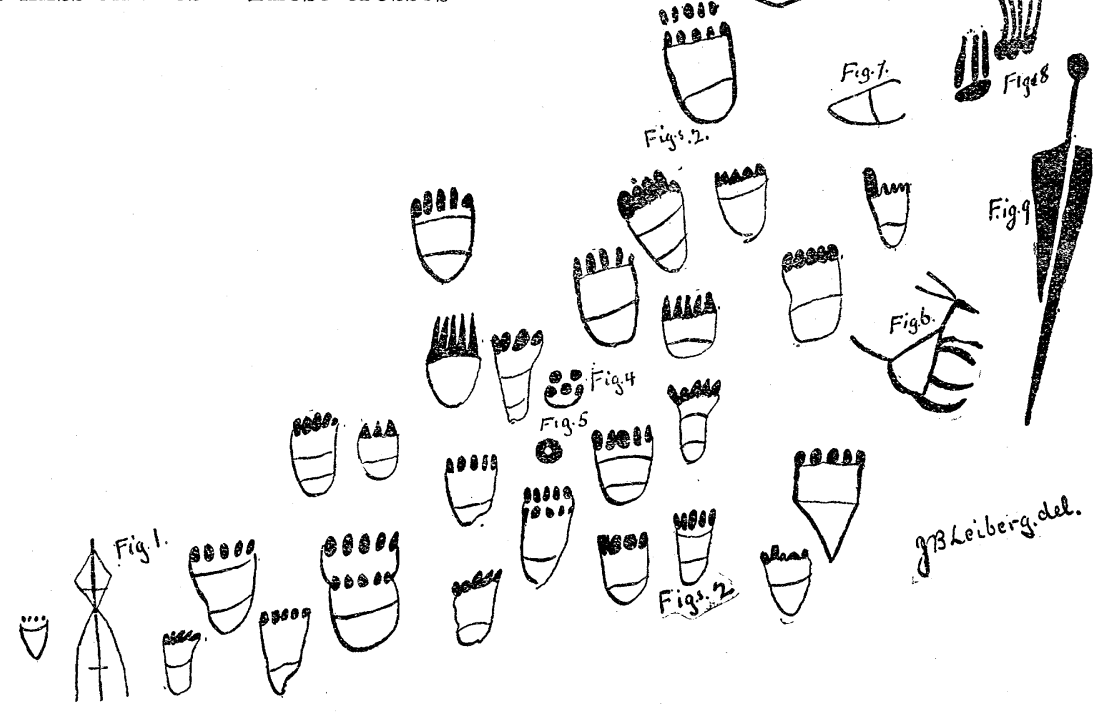

Scale one-twenty-fourth natural size.

are quite common around favorite hunting or camping spots in the mountains, and appear to be made with the object in view of warding off malign influences from the camping grounds. These crosses are not to be confounded with the sign plus, so commonly made by hunters and trappers throughout the deep forests, and which merely serve to attract attention to trails, locations of traps, etc.

The raised stones, so common on high peaks, merely denote the passing of some individual, and may be quite recent or date back a long time. Sometimes white men raise these rocks. The symmetrical arrangements of rocks appear to be quite ancient. The stones composing them lie quite flat and are completely covered with slowgrowing saxicoline lichens on all exposed portions. The import of these figures is unknown.

There is but one locality known to me in northern Idaho with true rock-carvings. It is located opposite the outlet of the Clark's Fork of the Columbia into Lake Pend d'Oreille, about one-quarter mile north from the shore. A rocky point of land rises abruptly to a height of 250 300 feet above the extensive marshes bordering the river at this point. The rock is a highly silicious magnesian schist, extremely hard and difficult to chisel with even the most carefully tempered modern steel tools. The to be traced with certainty. Nearly all the figures are thickly overgrown with close-clinging rock-lichens, rendering the whole quite inconspicuous. Close and diligent search has failed to bring any further inscriptions to light in the neighborhood.

One of the most interesting features in connection with this petrograph lies in the manner of its execution. The lines of the figures are not mere scratches, but are deep, wide grooves cut smoothly into this excessively hard rock, many of the grooves forming the representations of the bear tracks. Figs. 2 are $3.2 \mathrm{~cm}$. in width and $1.2 \mathrm{~cm}$. in depth, while the cutting forming fig. 3 is, in its broadest portion, $5.5 \mathrm{~cm}$. wide and $2.5 \mathrm{~cm}$. deep. The appearance of the grooves, the smoothness of the sides and freedom from signs of chipping give cause for the belief that they were cut into the rock by friction and not by chiseling. A piece of wood properly shaped and constantly charged with water and sharp sand could be used to cut such grooves, while the same manner of tool rotated by a bow would cut round holes such as make up fig. 10 . Will some of the readers of Science acquainted with the methods of the aborigines in making their rock inscriptions, inform us if such tools were in use elsewhere for doing this kind of work and the meaning of this petrograph? 